\title{
MODEL INTEGRASI MATEMATIKA DENGAN NILAI- NILAI ISLAM DAN KEARIFAN LOKAL BUDAYA DALAM PEMBELAJARAN MATEMATIKA
}

\author{
Mutijah \\ Program Studi Tadris Matematika, Institut Agama Islam Negeri \\ (IAIN) Purwokerto \\ mutijah1972@gmail.com
}

\begin{abstract}
Abstrak
Tulisan ini menyajikan gagasan tentang rumusan model integrasi matematika dan kearifan lokal budaya serta model integrasi matematika dengan nilai-nilai Islam dan kearifan lokal budaya yang dikembangkan melalui eksploratoris literatur. Model integrasi matematika dan kearifan lokal budaya dikembangkan atas dasar teori pembelajaran berbasis kearifan lokal. Sedangkan model integrasi matematika dengan nilai-nilai Islam dan kearifan lokal budaya dikembangkan atas dasar gagasan dari teori irisan himpunan antara model integrasi matematika dan Al Quran dengan model integrasi matematika dan kearifan lokal budaya. Tulisan ini juga menyajikan gagasan rumusan metode integrasi matematika dengan nilai-nilai Islam dan kearifan lokal budaya yang dikembangkan atas dasar teori metode integrasi sains dan Islam di Perguruan Tinggi Agama Islam. Model yang berhasil dikembangkan adalah model integrasi matematika dan kearifan lokal budaya yang meliputi model integrasi matematika dengan kearifan lokal budaya dan model integrasi matematika melalui kearifan lokal budaya serta berhasil dikembangkan model matematika dengan nilai-nilai Islam dan kearifan lokal budaya. Adapun metode yang berhasil dikembangkan dalam model integrasi matematika dengan nilai-
\end{abstract}


nilai Islam dan kearifan lokal budaya adalah menjadikan Al Quran dan kearifan lokal budaya sebagai sumber ilmu matematika, memperluas kajian karakteristik matematika dalam Al Quran dan budaya lokal, menjadikan kebudayaan Islam sebagai kepustakaan matematika, dan menumbuhkan karakter pribadi ulul albab yang berkearifan lokal budaya.

Kata Kunci: Integrasi, Nilai-Nilai Islam, Matematika, Budaya Lokal.

\begin{abstract}
This paper presents ideas about the formulation of models of mathematical integration and cultural local wisdom as well as models of mathematical integration with Islamic values and local wisdom of culture developed through exploratory literature. The model of integration of mathematics and local wisdom is developed on the basis of the theory of learning based on local wisdom. Whereas the model of mathematical integration with Islamic values and local wisdom of culture was developed on the basis of ideas from the theory of set slices between mathematical integration models and Al Quran with mathematical integration models and cultural local wisdom. This paper also presents the formulation ideas of mathematical integration methods with Islamic values and cultural local wisdom developed on the basis of the theory of methods of integration of science and Islam in Islamic Higher Education. The model that was successfully developed was a model of mathematical integration and cultural local wisdom which included mathematical integration models with local wisdom of culture and mathematical integration models through local cultural wisdom and successfully developed mathematical models with Islamic values and local cultural wisdom. The method that has been successfully developed in the mathematical integration model with Islamic values and local
\end{abstract}


wisdom of culture is to make the Qur'an and the local wisdom of culture as sources of mathematics, expand the study of the characteristics of mathematics in the Koran and local culture, make Islamic culture a mathematical literature, and fostering ulul albab's personal character that has local cultural wisdom.

Keywords: Integration, Islamic Values, Mathematics, Local Culture

\section{PENDAHULUAN}

Pasal 1 UU RI No. 20 Tahun 2003 mendefinisikan pendidikan adalah usaha sadar dan terencana untuk mewujudkan suasana belajar dan proses pembelajaran agar peserta didik secara aktif mengembangkan potensi dirinya untuk memiliki kekuatan spiritual keagamaan, pengendalian diri, kepribadian, kecerdasan, akhlak mulia, serta keterampilan yang diperlukan dirinya, masyarakat, bangsa, dan negara. Pendidikan dalam undang-undang tersebut bertujuan untuk berkembangnya potensi peserta didik agar menjadi manusia yang beriman dan bertaqwa kepada Tuhan Yang Maha Esa, berakhlak mulia, sehat, berilmu, cakap, kreatif, mandiri, dan menjadi warga negara yang demokrasi serta bertanggung jawab. Pendidikan juga merupakan proses alami dan memegang peranan penting dalam setiap kehidupan manusia. Dalam era modernisasi teknologi dan informasi seperti sekarang ini pendidikan harus mampu mengakomodasi kebutuhan setiap peserta didik agar mampu menghadapi tuntutan dan perubahan zaman. Tersirat juga makna dan tujuan pendidikan dalam undang-undang tersebut (pendidikan nasional) bahwa setiap peserta didik harus menjunjung tinggi nilai-nilai agama dan kebudayaan nasional dalam rangka membentuk pribadi yang beriman kepada Tuhan Yang Maha Esa, mengembangkan dan membentuk watak serta peradaban bangsa yang bermartabat untuk mencerdaskan kehidupan 
bangsa di era modernisasi ini. Tidak terkecuali seorang pribadi muslim sudah seharusnya menjunjung tinggi nilai-nilai islam dan budaya dalam rangka ikut mengembangkan pendidikan. Dapat dilihat dari konten UU RI No. 20 Tahun 2003 bahwa antara agama, budaya, dan pembelajaran adalah elemen-elemen yang saling mendukung dalam rangka membangun bangsa.

Upaya untuk mencapai tujuan pendidikan/pendidikan nasional maka pembelajaran matematika harus mengalami perubahan demi perbaikan mutu pendidikan dan pengembangan matematika itu sendiri yang diselaraskan dengan perkembangan ilmu pengetahuan dan teknologi. Maarif (2015) menyatakan kemajuan ilmu pengetahuan dan teknologi adalah salah satu cara dan sarana untuk mencapai perkembangan dunia muslim. Islam menyerukan umat Islam (muslim) mengejar ilmu pengetahuan, sebagaimana Nabi Muhammad mengatakan yang diriwayatkan oleh Ibnu Majah bahwa mencari ilmu adalah kewajiban bagi setiap muslim. Al Quran merupakan kitab suci umat Islam yang menjadi sumber dari semua sumber ilmu pengetahuan dalam praktiknya seharusnya tercermin di dalam keseluruhan perilaku hidup seorang muslim. Matematika sebagai ilmu pengetahuan, bahkan dijuluki sebagai raja dari ilmu maka matematika sudah pasti merupakan bagian dari $\mathrm{Al}$ Quran. Oleh karena itu, dalam mengembangkan ilmu pengetahuan dan perbaikan mutu pendidikan melalui pembelajaran matematika dirasa sangat penting untuk menciptakan suatu model pembelajaran matematika yang sesuai untuk menghadapi tantangan jaman sekarang dalam rangka mewujudkan tujuan luhur pendidikan/pendidikan nasional.

Model pembelajaran menurut Winataputra dalam Rianto (2006), menunjuk suatu kerangka konseptual yang melukiskan prosedur secara sistematis dalam mengorganisasikan pengalaman belajar untuk mencapai tujuan belajar tertentu dan berfungsi sebagai pedoman bagi para 

Mutijah

perancang pembelajaran dan para pengajar dalam merencanakan dan melaksanakan aktifitas pembelajaran. Model-model pembelajaran menurut Joyce\&Weil dalam Rusman (2018) biasanya disusun berdasarkan berbagai prinsip atau teori pengetahuan. Para ahli menyusun model pembelajaran berdasarkan prinsip-prinsip pendidikan, teoriteori psikologis, sosiologis, psikiatri, analisis sistem, atau teoriteori lain. Abdussakir ahli matematika dari UIN Malang telah menyusun atau mengembangkan model pembelajaran matematika supaya tercipta pembelajaran matematika yang sistematis dan terarah dalam rangka mewujudkan tujuan pendidikan/pendidikan nasional yakni model integrasi matematika dan Al Quran (Abdussakir dan Rosimanidar, 2017) dan (Abdussakir, 2018).

Agama, budaya, dan pembelajaran merupakan elemenelemen yang saling mendukung dalam rangka mewujudkan tujuan pendidikan/pendidikan nasional. Koentjaraningrat dalam Suwarsono (2015) menyatakan bahwa budaya (kebudayaan) adalah keseluruhan gagasan dan karya manusia yang harus dibiasakannya dengan belajar, beserta keseluruhan dari hasil budi dan karyanya itu. Menurut Heron dan Barta dalam Suwarsono (2015) juga menyatakan bahwa budaya dipandang sebagai dialek kelompok atau seseorang, geografi lokal atau pandangan dunia daripada pandangan yang terbatas sematamata terfokus pada artefak (benda sejarah/arkeologi) kelompok atau etnis (suku bangsa, biasanya berdasarkan garis keturunan) seseorang. Dituliskan dalam Arwanto (2017), budaya merupakan suatu kebiasaan yang mengandung unsur-unsur nilai penting dan fundamental yang diwariskan dari generasi ke generasi. Tisngati dalam Misnasanti, dkk (2016) menyatakan bahwa adat budaya merupakan salah satu kearifan lokal yang merupakan potensi daerah dan menjadi keunggulan lokal yang dapat dijadikan sebagai sumber belajar dalam pembelajaran. 
Agama Islam dalam perkembangannya tidak terlepas dari kebudayaan Islam. Menurut Picktchall dalam Widyastini (2004) kebudayaan Islam merupakan suatu sistem yang memiliki sifat-sifat ideal, sempurna, praktis, aktual, diakui keberadaannya dan senantiasa diekspresikan. Perkembangan kebudayaan Islam membutuhkan petunjuk wahyu berupa firman-firman Allah SWT yang terdapat di dalam Al Quran dan diperlukan seorang pemimpin umat yaitu Nabi sekaligus Rasulullah Muhammad SAW, serta bertujuan semata-mata hanya untuk beribadah kepada Allah. Nabi Muhammad SAW dalam mengawali tugas kenabian dan kerasulannya mendasarkan diri pada asas-asas kebudayaan Islam yang selanjutnya tumbuh dan berkembang menjadi suatu peradaban Islam. Peradaban Islam adalah beradaban yang mengandung nilai-nilai Islam, sedangkan peradaban dalam arti luas yaitu merupakan kumpulan suatu identitas terluas dari seluruh hasil budidaya manusia yang mencakup seluruh kehidupan manusia baik fisik (misal bangunan) maupun non fisik (nilai-nilai, tatanan, seni budaya, ataupun IPTEK) yang terindentifikasi dengan melalui unsur-unsur obyektif umum, seperti halnya bahasa, sejarah, agama, kebiasaan, institusi ataupun melalui identifikasi diri yang subyektif. Nabi Muhammad SAW pada waktu berdakwah keluar dari jazirah Arab dan seterusnya menyebar ke seluruh penjuru dunia maka terjadi proses asimilasi berbagai macam kebudayaan dengan nilai-nilai Islam kemudian menghasilkan kebudayaan Islam yang pada akhirnya berkembang menjadi suatu kebudayaan yang diyakini kebenarannya secara universal. Setelah Nabi Muhammad SAW wafat, penyebaran agama Islam diteruskan oleh para Ulul Albab yang melakukan dakwahnya juga mendasarkan pada asas-asas kebudayaan Islam disesuaikan dengan daerahnya masing-masing. Di daerah jawa misalnya, para Ulul Albab dikenal dengan sebutan Wali Songo. 
Berdasar pada pemaparan di atas, adapun yang menjadi permasalahan dalam penelitian ini adalah bagaimana model integrasi matematika dengan nilai-nilai Islam dan kearifan lokal budaya dalam pembelajaran matematika?

\section{METODE PENELITIAN}

Penelitian ini merupakan penelitian kualitatif studi literature yang dimaksudkan untuk mendeskripsikan model integrasi matematika dengan nilai-nilai Islam dan kearifan lokal budaya dalam pembelajaran matematika. Adapun metode pengumpulan data dilakukan dengan dokumentasi dan kajian literatur. Adapun teknik analisis data yang digunakan dalam penelitian ini merupakan content analysis.

\section{HASIL PENELITIAN DAN PEMBAHASAN Model Integrasi Matematika dan Nilai-nilai Islam}

Integrasi sains (matematika) dan agama (islam) bertujuan untuk menyeimbangkan sisi intelektual dan spiritual. Namun untuk umat islam (muslim) juga berguna untuk mengenang kejayaan matematikawan muslim dalam pengembangan ilmu pengetahuan (matematika) seperti Al Khawarizmi sebagai tokoh terbesar dalam ilmu aljabar dan aritmatika, Ibn AlHaytham sebagai salah seorang fisikawan muslim terkemuka selain juga sebagai ahli astronomi, filosofi, kedokteran, dan ahli matematika dalam bidang geometri dan aritmatika, Al-Biruni seorang ahli kronologi, geografi matematika, fisika, kimia, mineralogi, sejarah, antropologi, agama, kedokteran, astrologi, puisi, dan ahli matematika di bidang geometri, aritmatika (termasuk bilangan $\pi$ ), trigonometri, Omar Khayyam ahli di bidang geometri dan aljabar, serta Al Tusi seorang ahli geometri dan trigonometri (Mohamed, 2001). Sejarah tokohtokoh matematika tersebut menunjukkan bahwa matematikawan muslim mengembangkan matematika terintegrasi dengan agama karena selain mereka ilmuwan juga 
tokoh agama islam. Sedangkan dalam konsep pembelajaran, integrasi matematika dan nilai-nilai Islam khususnya integrasi matematika dan Al Quran merupakan sebuah model pembelajaran yang dapat diterapkan dalam pembelajaran matematika baik di tingkat pendidikan dasar, menengah, ataupun pendidikan tinggi. Akhir-akhir ini model integrasi matematika dan Al Quran dalam pembelajaran matematika telah dikembangkan, berikut review model integrasi yang dirumuskan oleh Abdussakir (2018).

1. Mengembangkan Matematika dari Al Quran (Mathematics from Al Quran).

Model integrasi ini mengkaji dan mengembangkan matematika dari Al Quran. Implementasi dalam praktik, pembelajaran dimulai dari mengkaji ayat-ayat Al Quran. Salah satu contoh misalnya dalam pembelajaran statistika dasar di perguruan tinggi dapat dimulai dengan mengkaji surat Al Kahfi ayat 96 untuk membelajarkan mean, Al Kahfi ayat 54 untuk membelajarkan modus, Al Maidah ayat 66 untuk membelajarkan median, dan tentang hipotesis bisa dimulai dengan mengkaji surat Al Baqarah ayat 78, Yunus ayat 66, Saba' ayat 53, Az Zukhruf ayat 20 serta Al Jasiyah ayat 24 dan 32 .

2. Menggunakan matematika untuk melaksanakan Al Quran (Mathematics for Al Quran)

Model integrasi ini diartikan bahwa matematika digunakan untuk melaksanakan perintah-perintah Allah yang termuat dalam Al Quran, dan dalam praktik pembelajarannya matematika diajarkan dalam rangka mengembangkan potensi intelektual dan spiritual. Contoh dari model integrasi ini misalnya menggunakan matematika untuk penentuan arah kiblat, untuk penentuan waktu sholat, untuk penentuan zakat dan warisan, serta yang lainnya.

3. Menggunakan matematika untuk menguak keajaiban matematis Al Quran (Mathematics to Al Quran). 
Model integrasi ini meliputi model matematika untuk mengeksplorasi (Mathematics to Explore), menjelaskan (Mathematics to Explain) dan menyampaikan (Mathematics to Deliver) Al Quran yakni berturut-turut matematika digunakan untuk mengeksplorasi keajaiban-keajaiban matematis yang terdapat dalam Al Quran, matematika digunakan untuk penjelasan pada ayat Al Quran yang berkaitan dengan perhitungan matematis dan aspek matematika lainnya, dan matematika digunakan sebagai sarana untuk mengajarkan dan menyampaikan kandungan materi Al Quran.

4. Mengajarkan matematika dengan nilai-nilai Al Quran (Mathematics with Al Quran)

Rumusan dalam model ini adalah matematika dikaitkan dengan kandungan nilai-nilai Al Quran yang kemudian diinternalisasikan ke dalam pembelajaran matematika. Matematika dilandasi nilai-nilai Al Quran untuk mengembangkan akhlak mulia. Dalam praktik pembelajaran matematika, mengajarkan matematika dilakukan dengan strategi infusi (guru menekankan aspek nilai Al Quran yang ada dalam materi dalam mengajarkan matematika), analogi (guru melakukan analogi nilai kebaikan dalam mengajarkan matematika), narasi (dalam mengajarkan matematika guru menceritakan kisah-kisah matematika dan matematikawan muslim untuk diambil hikmahnya), dan Uswah Hasanah (dalam mengajarkan matematika guru menunjukkan perilaku yang patut dicontoh terkait matematika, misalnya kejujuran, kesungguhan, ketepatan, ketaatan, dan ketelitian).

\section{Model Integrasi Matematika dan Kearifan Lokal Budaya}

Pendidikan dan kebudayaan merupakan satu kesatuan yang saling mendukung dan menguatkan. Kebudayaan menjadi dasar falsafah pendidikan sementara pendidikan menjadi penjaga utama kebudayaan karena peran pendidikan 
membentuk orang untuk berbudaya. Era sekarang ini perlu pencegahan dan pengantisipasian pada peningkatan degradasi moral. Pendidikan yang menitikberatkan pada kualitas manusia yang berbudi pekerti luhur, beradab, dan berwawasan keilmuan yang mumpuni selanjutnya menjadi tuntutan pada era sekarang ini. Ki Hadjar Dewantara dalam Indriaini (2016) menyatakan bahwa tugas lembaga pendidikan bukan hanya mengajar untuk menjadikan orang pintar, pandai, berpengetahuan, dan cerdas tetapi untuk menumbuhkan budi pekerti dalam kehidupan agar supaya menjadi manusia yang berpribadi, beradab, dan berbudaya. Sebagai manusia budaya ia sanggup dan mampu mencipta segala sesuatu yang bercorak luhur dan indah, yakni yang disebut kebudayaan. Pandangan Ki Hadjar Dewantara ini mengandung makna bahwa budaya memuat nilai-nilai budi pekerti bangsa yang luhur.

Salah satu cara untuk menanamkan nilai budi pekerti yang luhur adalah dengan mengintegrasikan kearifan lokal ke dalam proses pembelajaran. Mengintegrasikan kearifan lokal dalam pembelajaran berfungsi mendesain pembentukan karakter individu, secara tidak langsung individu akan mendapatkan gambaran yang utuh atas identitas dirinya dan identitas dirinya sebagai anggota masyarakat yang terikat dengan budaya yang telah dipelihara oleh para pendahulunya. Selain itu pendidikan berbasis kearifan lokal mengembangkan individu peserta didik mampu mengembangkan pengetahuannya yang bersumber pada kearifan lokal masyarakat setempat, memiliki keterampilan dalam memahami masyarakat pada proses kehidupan, dan memiliki sikap dan perilaku yang selaras dengan kearifan lokal tersebut (Lukluah, 2016). Kearifan lokal adalah merupakan gagasan-gagasan setempat (lokal) yang bersifat bijaksana, penuh kearifan, bernilai baik yang tertanam dan diikuti oleh anggota masyarakat. Kearifan lokal dipengaruhi oleh kebudayaan dari masing-masing daerah. (Umbara, 2015). Hal ini sejalan dengan 

Mutijah

rekomendasi UNESCO (2016) mengenai pentingnya penggalian kearifan lokal sebagai dasar pendidikan karakter dan pendidikan pada umumnya karena sebagian besar sistem pendidikan formal lebih menekankan pada pengetahuan abstrak tanpa menghubungkan pembelajaran dengan aspek kehidupan sehari-hari yang dekat dengan budaya lokal (Misnasanti,dkk, 2016). Rekomendasi UNESCO ini memberikan arahan bahwa kearifan lokal perlu diintegrasikan ke dalam materi ajar, termasuk di dalamnya materi ajar matematika, artinya bahwa untuk menanamkan nilai budi pekerti yang luhur dapat dilaksanakan melalui pembelajaran matematika.

Ruang lingkup kearifan lokal sangat luas, tergantung dari perspektif apa yang digunakan dalam memandang kearifan lokal itu sendiri. Kearifan lokal milik bangsa Indonesia sangat banyak dan beraneka ragam karena Indonesia terdiri dari bermacam-macam suku bangsa, berbicara dalam aneka bahasa daerah, dan menjalankan ritual adat yang berbeda-beda pula. Menurut Lukluah (2016) bahwa yang termasuk dalam kearifan lokal adalah unsur budaya dan non budaya yang relevan dengan masyarakat setempat. Sedangkan dimensi fisik dalam Lukluah (2016) meliputi upacara adat, cagar budaya, pariwisata alam, transportasi tradisional, permainan tradisional, prasarana budaya, pakaian adat, warisan budaya, museum, lembaga budaya, kesenian, desa budaya, kesenian dan kerajinan, cerita rakyat, dolanan anak, dan wayang. Dengan demikian kearifan lokal merupakan bagian dari budaya dan merupakan sebuah budaya kontekstual yang bersumber dari hidup manusia. Konteks dalam pembelajaran, Putri (2017) dan Indriaini (2016) dalam tulisannya menyatakan pembelajaran berbasis budaya dapat dibedakan menjadi 3 (Tiga) macam yaitu belajar tentang budaya; belajar dengan budaya; dan belajar melalui budaya. Ada 4 (Empat) hal yang harus diperhatikan dalam pembelajaran berbasis budaya yakni substansi dan kompetensi bidang 
ilmu/bidang studi; kebermaknaan dan proses pembelajaran; dan penilaian hasil belajar; dan peran budaya.

Berdasar pada substansi dan kompetensi bidang ilmu/bidang studi sudah semestinya bahwa pembelajaran berbasis budaya keberlakuannya adalah umum yakni berlaku umum untuk semua bidang ilmu tanpa kecuali matematika. Hal tersebut tersirat secara implisit bahwa pembelajaran berbasis budaya terintegrasi dengan bidang keilmuan lainnya. Oleh karena itu dengan mengacu pada pembelajaran berbasis budaya maka dalam konteks pembelajaran matematika berbasis kearifan lokal budaya memiliki makna yaitu belajar tentang matematika dan kearifan lokal budaya itu sendiri, belajar matematika dengan kearifan lokal budaya, dan belajar matematika melalui kearifan kokal budaya.

Berangkat dari hal ini dan mengacu pada dasar pengembangan model integrasi matematika dan Al Quran selanjutnya dapat dikembangkan model integrasi matematika dan kearifan lokal budaya dalam praktik pembelajaran yakni model

1. Integrasi matematika dengan kearifan lokal budaya (Mathematics with culture local wisdom).

Matematika dikaitkan dengan kandungan nilai-nilai luhur kearifan lokal budaya. Dalam mengajar matematika melakukan internalisasi nilai-nilai luhur kearifan lokal budaya. Merujuk pada Abdussakir (2017) dan Abdussakir (2018) maka model integrasi matematika dengan kearifan lokal budaya ini dapat dilakukan dengan strategi infusi, analogi, narasi, dan uswah hasanah. Sebagai contoh dalam mengajar matematika dapat menginternalisasikan nilai luhur dari kearifan lokal budaya (strategi infusi). Misalnya nilai luhur dari hasil budaya yang berupa bangunan Masjid Saka Tunggal di Desa Cikakak, Kecamatan Wangon, Kabupaten Banyumas dikaitkan dengan matematika ketika mengajarkan 
pembuktian bahwa sebarang bilangan riil jika dipangkatkan dengan 0 (nol) hasilnya 1 (satu), yaitu sebagai berikut:

$$
\forall a \in \mathbb{R} \rightarrow a^{0}=1
$$

Nilai yang terkandung dalam matematika tersebut bahwa jika kita membuat 0 (nol) pikiran kita (berpasrah diri pada Allah SWT) maka justru akan mendapatkan sesuatu yang sempurna. Sebagaimana digambarkan dari bangunan Masjid Saka Tunggal bahwa orang yang senantiasa berpasrah diri pada Allah SWT (senantiasa datang ke rumah Allah SWT) akan mendapatkan 1 (satu) pondasi dasar yang kuat dalam hidup.

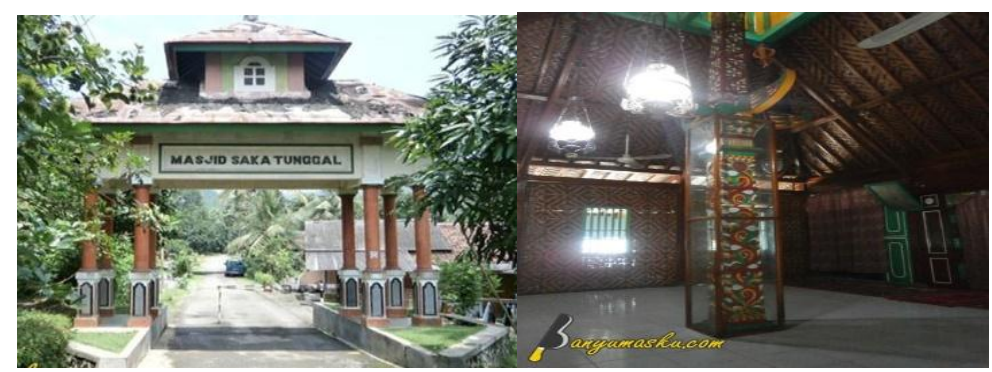

\section{Gambar 1.}

Masjid Saka Tunggal Banyumas

2. Integrasi matematika melalui kearifan lokal budaya (Mathematics through culture local wisdom).

Mengajarkan matematika melalui eksplorasi matematika yang terkandung dalam kearifan lokal budaya. Pembelajaran matematika yang dalam mengajarkannya dilakukan dengan mengeksplorasi budaya lokal daerah dikenal dengan pembelajaran berbasis budaya lokal dan lebih umum disebut dengan etnomatematika. Misalkan dalam mengajarkan volume tabung bisa mengeksplorasi dari hasil budaya lokal Banyumas yaitu Kentongan dengan 
mengeksplorasi alat-alat musik yang dimainkan dalam Kentongan Banyumas.

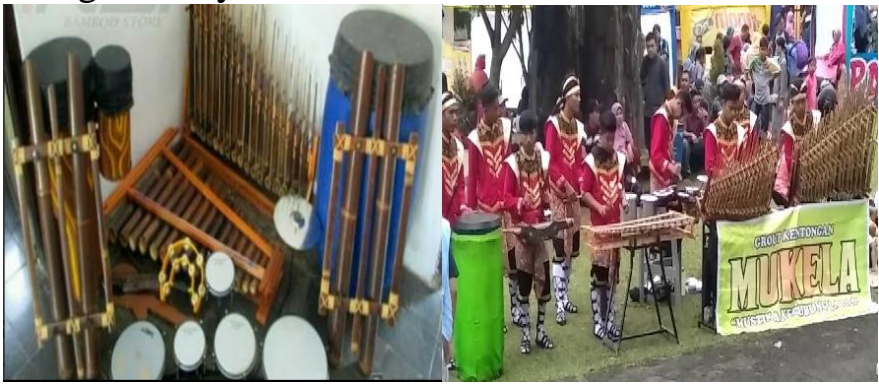

Gambar 2.

Alat Musik dan Grup Kentongan Banyumas

\section{A. Model Integrasi Matematika dengan Nilai-nilai Islam dan Kearifan Lokal Budaya serta Metodenya.}

Model integrasi matematika dengan nilai-nilai Islam dan kearifan lokal budaya ini dikembangkan atas dasar gagasan dari teori irisan himpunan antara model integrasi matematika dan Al Quran dengan model integrasi matematika dan kearifan lokal budaya. Ilustrasi gagasan rumusan model integrasi matematika dengan nilai-nilai Islam dan kearifan lokal budaya dari teori irisan himpunan dalam gambar 3.

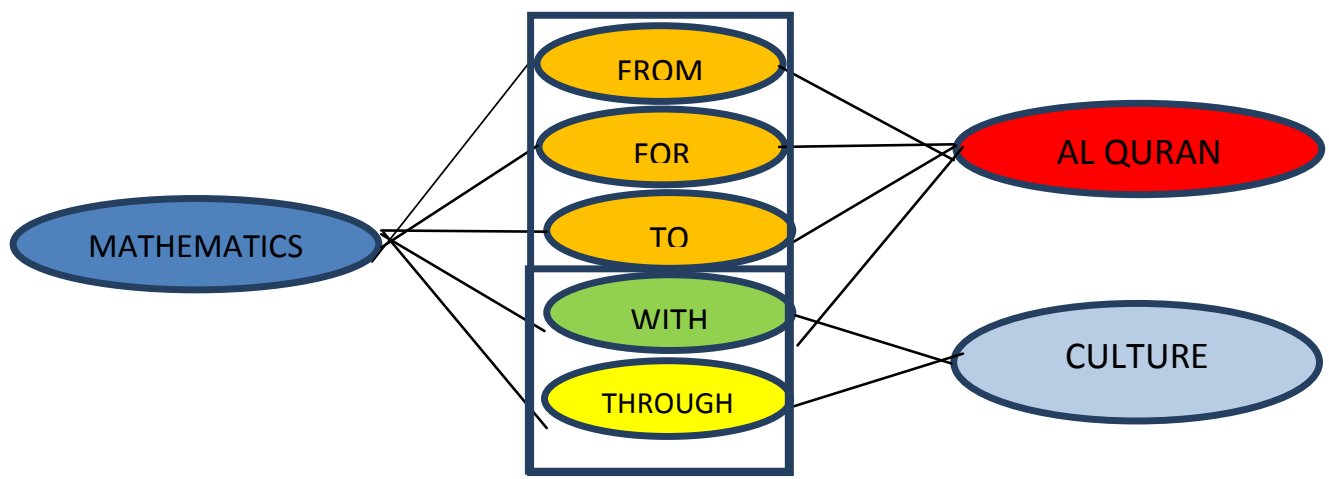

Gambar 3. Dasar Gagasan Rumusan Model Integrasi 
Suatu model pembelajaran yang digunakan untuk menyampaikan tujuan pembelajaran akan terlaksana secara sistematis dan terarah serta mudah dalam mempelajari suatu materi tertentu jika disampaikan dengan suatu metode yang sesuai. Metode berhubungan dengan cara yang memungkinkan seseorang memperoleh kemudahan dalam rangka mempelajari sesuatu. Metode yang dikembangkan dalam pembelajaran yang menerapkan model ini diusulkan sebagai berikut:

1. Menjadikan Al Quran dan kearifan lokal budaya sebagai sumber ilmu matematika.

Implementasinya dalam praktik pembelajaran matematika dilakukan dengan cara menelusuri ayat-ayat $\mathrm{Al}$ Quran dan kearifan lokal budaya sebagai sumber untuk mengajarkan materi matematika. Misalnya materi himpunan dapat ditelusuri dari Al Quran dan kearifan lokal budaya yaitu QS. Al An'am ayat 128 yang bunyi dan artinya

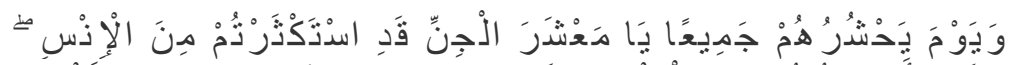

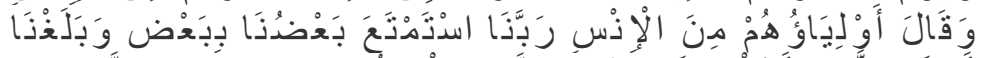

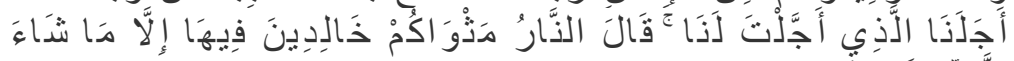

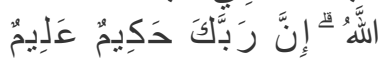

"Dan (ingatlah) hari diwaktu Allah menghimpunkan mereka semuanya (dan Allah berfirman): "Hai golongan jin, sesungguhnya kamu telah banyak menyesatkan manusia", lalu berkatalah kawan-kawan meraka dari golongan manusia: "Ya Tuhan kami, sesungguhnya sebahagian daripada kami telah dapat kesenangan dari sebahagian (yang lain) dan kami telah sampai kepada waktu yang telah Engkau tentukan bagi kami". Allah berfirman: "Neraka itulah tempat diam kamu, sedang kamu kekal di dalamnya, kecuali kalau Allah menghendaki (yang lain)". 
Sesungguhnya Tuhanmu Maha Bijaksana lagi Maha Mengetahui”.

Kentongan Banyumas merupakan contoh kearifan lokal budaya terdiri himpunan orang laki-laki (pemain musiknya), himpunan orang perempuan (penarinya) dan himpunan alat musik. Dalam materi himpunan dapat digambarkan

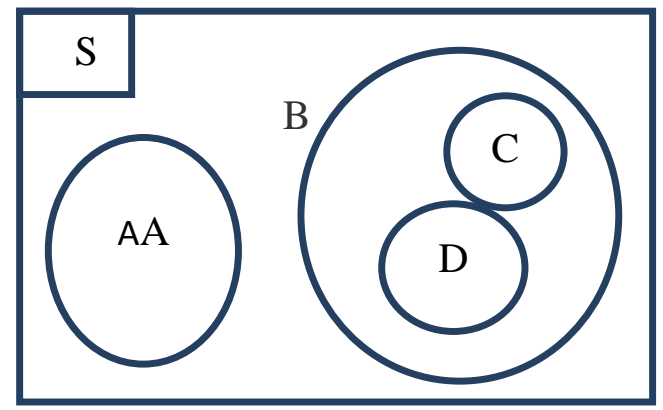

Gambar 4. Diagram Venn

$\mathrm{S}=$ Makhluk ciptaan Allah

$\mathrm{A}=$ Golongan jin

$\mathrm{B}=$ Golongan manusia

$\mathrm{C}=$ Manusia berjenis kelamin laki-laki

$\mathrm{D}=$ Manusia berjenis kelamin perempuan

Diagram Venn yang digambarkan dalam ayat dan budaya Kentongan di atas adalah dua himpunan saling lepas dan dua himpunan yang merupakan himpunan bagian dari himpunan lain.

2. Memperluas kajian karakteristik matematika dalam Al Quran dan kearifan lokal budaya.

Dalam mengajarkan matematika, Al Quran dan budaya lokal dijadikan sebagai sumber untuk menelusuri karakteristik matematika yang ada dalam Al Quran sekaligus ada dalam budaya lokal. Misalnya mengajarkan statistika 
(cabang matematika) dalam pengambilan data tanpa ada manipulasi data atau membuktikan suatu teorema tanpa ada manipulasi langkah dan penggunaan sifat, lemma, atau teorema yang lain. Dalam hal ini memuat aspek kejujuran matematika. Aspek kejujuran dalam matematika dapat ditemukan dalam Al Quran yaitu QS. At-Taubah Ayat 119.

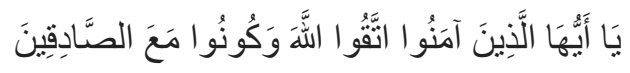

yang artinya: "Wahai orang-orang yang beriman, bertaqwalah kepada Allah dan bersamalah kamu dengan orang-orang yang jujur".

Bahkan Allah SWT menjanjikan manfaat dari kejujuran, sebagaimana dalam QS. Al Maidah Ayat 119.

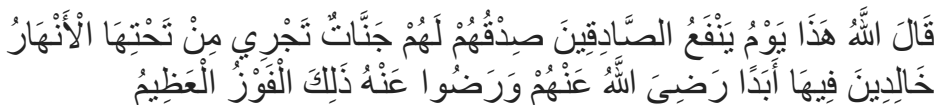

Artinya Allah berfirman: "Inilah saat orang yang jujur memperoleh manfaat dari kejujurannya. Mereka memperoleh surga yang di bawahnya mengalir sungaisungai, mereka kekal di dalamnya selama-lamanya. Allah ridha kepada mereka dan merekapun ridha kepada-NYA. Itulah kemenangan yang Agung".

Aspek kejujuran dalam matematika dapat ditemukan pada budaya lokal Banyumasan yang dikenal dengan CABLAKA atau BLAKASUTA. Kejujuran tercermin dari dialek atau bahasa cablaka atau blakasuta yang mengatakan apa adanya atau yang sebenarnya atau sering disebut blak-blakan.

3. Menjadikan kebudayaan Islam sebagai kepustakaan matematika 
Pada prinsipnya azas Islam atau dasar hukum Islam mengandung kepustakaan yakni pada waktu turunnya firman Allah yang pertama Surat Al Alaq ayat 1-5 yang artinya

"Bacalah dengan menyebut nama Tuhanmu yang menciptakan. Dia telah menciptakan manusia dari segumpal darah. Bacalah dan Tuhanmulah yang maha pemurah. Yang mengajar manusia dengan perantaraan kalam. Dia mengajarkan manusia apa yang tidak diketahuinya".

Ayat tersebut mengandung makna bahwa tempat bersandar kepustakaan adalah membaca dan menulis. Sedangkan membaca dan menulis merupakan pertanda bagi lahirnya kepustakaan Islam sesudah Nabi wafat. Kepustakaan Islam adalah pusat pendidikan, pengajaran, dan dakwah Islam (Widyastini, 2004). Sejalan dengan ini maka kepustakaan matematika dapat diberi makna sebagai pusat pendidikan dan pengajaran matematika.

Jika menengok ke belakang dari awal penyebaran agama islam ke seluruh dunia dengan menggunakan kebudayaan Islam sebagai sarananya maka sudah pasti sampai sekarang telah berkembang banyak kebudayaan islam pada suatu daerah-daerah tertentu. Contoh kebudayaan Islam yang berupa pesan yang disampaikan oleh Sunan Gunung Jati, salah satu Wali Songo di daerah Cirebon Jawa Barat, "Ingsun Titip Tajug lan Fakir Miskin". Ingsun Titip Tajug artinya saya menitipkan Masjid. Masjid adalah merupakan pusat kebudayaan islam dan peradaban Islam. Melalui bangunan fisik masjid banyak sekali konsep matematika yang terkandung di dalamnya, disamping itu juga masjid merupakan simbol kesinergian hubungan antara hamba 
dengan Tuhannya (hablum minallah). Ingsun Titip Fakir Miskin artinya saya menitipkan fakir miskin. Fakir miskin mengandung makna kesinergian antara sesama manusia (hablum minannas). Konsep matematika tentang relasi, bidang kartesius, dan orthogonalitas serta lainnya dapat dikembangkan dari kebudayaan Islam yang berupa pesan ini. Pesan ini sekaligus memuat dua kebudayaan Islam yang dapat dijadikan sebagai kepustakaan matematika yakni Pesan itu sendiri dan Masjid.

4. Menumbuhkan pribadi berkarakter Ulul Albab yang berkearifan lokal budaya.

Ulul Albab dalam Batubara (2016) adalah orangorang yang memiliki akal yang murni, tidak diselimuti oleh kemaksiatan yang dapat melahirkan kerancuan dalam berpikir. Sebagaimana tanda-tanda kemurnian berpikir orang yang dikategorikan Ulul Albab dijelaskan juga dalam firman Allah Q.S. Ali Imron ayat 189-191 yang artinya "kepunyaan Allah-lah kerajaan langit dan bumi dan Allah maha perkasa atas segala sesuatu. Sesungguhnya dalam penciptaan langit dan bumi, dan silih bergantinya malam dan siang terdapat tanda-tanda bagi orang yang berakal (yaitu) orang-orang yang mengingat Allah sambil berdiri atau duduk atau dalam keadaan berbaring dan mereka memikirkan tentang penciptaan langit dan bumi". Dalam Ayat ini terkandung makna bahwa Allah memberikan cara untuk manusia memikirkan tentang ciptaan dan mengingatNYA. Sedangkan karakter Ulul Albab dalam Batubara (2016) diformulasikan secara rinci bahwa (1) memiliki akar pikiran yang murni dan jernih serta mata hati yang tajam dalam menangkap fenomena yang dihadapi, memanfaatkan kalbu untuk zikir kepada Allah dan memanfaatkan akal (pikiran) untuk mengungkap 
rahasia alam semesta, giat melakukan kajian dan penelitian untuk kemaslahatan hidup, suka merenungkan dan mengkaji ayat-ayat (tanda-tanda kekuasaan dan kebenaran)-Nya dan berusaha menangkap pelajaran darinya, serta berusaha mencari petunjuk dan pelajaran dari fenomena historik atau kisah-kisah terdahulu,(2) selalu sadar diri akan kebesaran Allah dalam segala situasi dan kondisi, (3) lebih mementingkan kualitas hidup (jasmani dan rohani) daripada kuantitas, (4) mampu menyelesaikan masalah dengan adil, (5) siap dan mampu menciptakan kehidupan yang harmonis dalam kehidupan keluarga maupun masyarakat, (6) mampu memilih dan menerapkan jalan yang benar dan baik yang diridloi oleh Allah serta mampu membedakan mana yang lebih atau kurang bermanfaat dan menguntungkan bagi kehidupannya di dunia dan di akhirat, (7) menghargai khasanah intelektual dari para pemikir, cendekiawan atau ilmuan sebelumnya, (8) bersikap terbuka dan kritis terhadap pendapat, ide atau teori dari manapun datangnya dan untuk selanjutnya berusaha dengan sungguh-sungguh dalam mengikuti pendapat, ide, atau teori yang terbaik, (9) sabar dan tahan uji walaupun ditimpa musibah dan diganggu oleh syetan (jin dan manusia), (10) sadar dan peduli terhadap pelestarian lingkungan hidup, dan (11) tidak mau membuat onar, keresahan dan kerusakan, serta berbuat maker di masyarakat.

Dalam konteks metode ini bahwa karakter dari seorang pribadi Ulul Albab secara umum adalah merupakan nilai-nilai budi pekerti yang luhur yang dapat diterapkan dimanapun dan kapanpun. Akibatnya karakter pribadi Ulul Albab semestinya juga dapat tumbuh dalam suatu daerah dan budaya tertentu (lokal). 
Di sisi lain dalam karakter pribadi Ulul Albab tersebut tersirat kandungan aspek-aspek matematika yang dapat ditumbuhkan dalam pembelajaran matematika. Praktik dalam pembelajaran matematika dilakukan dengan mengkaji konsep matematika dari kearifan lokal budaya yang digunakan atau dibawakan atau disajikan oleh seorang Ulul Albab dan dengan mengkaji karakter yang ada pada Ulul Albab tersebut. Misalkan akan mengajarkan materi fungsi dalam matematika dengan mengkaji orang berdzikir di dalam Masjid. Masjid merupakan hasil budaya lokal dan orang berdzikir di dalam Masjid dipastikan memiliki karakter pribadi $U l u l$ Albab (memiliki pikiran jernih). Maka dalam aktifitas dzikir oleh seorang Ulul Albab terdapat suatu materi fungsi yakni pemetaan antara lafadz dzikir (tasbih, tahmid, takbir, dan lain lain) dengan suatu bilangan bulat sebab masing-masing lafadz dzikir tersebut biasanya dalam berdzikir dilafadzkan sebanyak 33 kali. Dalam matematika dituliskan $: \mathrm{x} \rightarrow \mathrm{k}$, dengan $\mathrm{x}$ adalah lafadz dzikir dan $\mathrm{k}$ adalah bilangan konstan.

\section{SIMPULAN}

Berdasar pada model integrasi matematika dan kearifan lokal budaya dikembangkan atas dasar teori pembelajaran berbasis kearifan lokal. Sedangkan model integrasi matematika dengan nilai-nilai Islam dan kearifan lokal budaya dikembangkan atas dasar gagasan dari teori irisan himpunan antara model integrasi matematika dan Al Quran dengan model integrasi matematika dan kearifan lokal budaya. Tulisan ini juga menyajikan gagasan rumusan metode integrasi matematika dengan nilai-nilai Islam dan kearifan lokal budaya yang dikembangkan atas dasar teori metode integrasi sains dan Islam 
di Perguruan Tinggi Agama Islam. Model yang berhasil dikembangkan adalah model integrasi matematika dan kearifan lokal budaya yang meliputi model integrasi matematika dengan kearifan lokal budaya dan model integrasi matematika melalui kearifan lokal budaya serta berhasil dikembangkan model matematika dengan nilai-nilai Islam dan kearifan lokal budaya. Adapun metode yang berhasil dikembangkan dalam model integrasi matematika dengan nilai-nilai Islam dan kearifan lokal budaya adalah menjadikan Al Quran dan kearifan lokal budaya sebagai sumber ilmu matematika, memperluas kajian karakteristik matematika dalam Al Quran dan budaya lokal, menjadikan kebudayaan Islam sebagai kepustakaan matematika, dan menumbuhkan karakter pribadi ulul albab yang berkearifan lokal budaya.

\section{DAFTAR PUSTAKA}

Abdussakir dan Rosimanidar. 2017. Model Integrasi Matematika dan Al Quran serta Praktik Pembelajarannya, Makalah Seminar Nasional Integrasi Matematika di dalam Al Quran, HMJ Pendidikan Matematika Bukittinggi, 26 April 2017.

Abdussakir. 2018. Integrating Mathematics and Religious Teachings and Values in Elementary and Secondary School, Keynote Speaker Full Paper dalam International Conference on Mathematics and Islam.

Arwanto. 2017. Eksplorasi Etnomatematika Batik Trusmi Cirebon untuk Mengungkap Nilai Filosofi dan Konsep Matematis, journal.walisongo.ac.id/index.php/Phenomenon/article/V iewFile/1493/1106. 
73 | MODEL INTEGRASI MATEMATIKA DENGAN NILAI ISLAM Mutijah

Batubara, H.H. 2016. Metode dan Model Integrasi Sains dan Islam di Perguruan TinggiIslam. Tersedia: [online]. http://www.reserchgate.net/publication/324744404_Meto de_dan_Model_Integrasi_Sains_dan_Islam_di_Perguruan _Tinggi_Islam

Bayu, D. 2012. Statistika dalam Agama Islam. Tersedia [online] https://otakngepas.blogspot.com/2012/04/pendahuluan$\underline{1 . \mathrm{html}}$

Fitriatien, S.R. 2016. Pembelajaran Berbasis Etnomatematika. Conference Paper. December 2016.

Ikhwanudin, T. 2018. Pembelajaran Matematika Berbasis Kearifan Lokal untuk Membangun Karakter Bangsa, UNION: Jurnal Pendidikan Matematika, Vol 6, No 1, Maret 2018.

Indriaini, P. 2016. Implementasi Etnomatematika Berbasis Budaya Lokal dalam Pembelajaran Matematika pada Jenjang Sekolah Dasar. Jurusan Pendidikan Matematika IAIN Raden Intan Lampung.

Lukluah, U. 2016. Pengembangan Bahan Ajar Tematik Berbasis Islam dan Kearifan Lokal Kelas IV MIN Bancong dan MIS Al Fatah Dimong Kabupaten Madiun. Tesis. PGMI Pascasarjana UIN Maulana Malik Ibrahim Malang.

Maarif, S. 2015. Integrasi Matematika dan Islam dalam Pembelajaran Matematika, Infinity Jurnal Ilmiah Program Studi Matematika STKIP Siliwangi Bandung, Vol 4, No.2, September 2015. 
Misnasanti, Cendekia Ad Dien, dan Astuti, AD. 2016. Internalisasi Nilai-Nilai Kearifan Lokal pada Pembelajaran Matematika di Era Post-Modern, Proceding Seminar Nasional Matematika Ahmad Dahlan, ISBN 978-979-3812-46-5.

Mohamed, M. 2001. Matematikawan Muslim Terkemuka. Jakarta: Salemba Teknika

Nasuha. 2010. Sejarah, Seni, dan Budaya Banyumas, Makalah. Tersedia [online]: http://smithnasuha.blogspot.com/2010/10/sejarah-senidan-budaya-banyumas.html

Nihayati. 2017. Integrasi Nilai-nilai Islam dengan Materi Himpunan (Kajian terhadap Ayat-ayat Al Quran), Jurnal Edumath, Volume 3 No. 1, Januari 2017 Hlm. 65-77.

Putri, L.I. 2017. Eksplorasi Etnomatematika Kesenian Rebana sebagai Sumber Belajar Matematika pada Jenjang MI. Jurnal Ilmiah PENDIDIKAN DASAR, Vol. IV, No.1, Januari 2017.

Rianto, M. 2006. Pendekatan, Strategi, dan Metode Pembelajaran. Departemen Pendidikan Nasional, Dirjend Peningkatan Mutu Pendidik dan Tenaga Kependidikan, Pusat Pengembangan Penataran Guru IPS dan PMP Malang.

Rusman. T.th. Materi-8 Pendekatan dan Model Pembelajaran. Tersedia [online]:

file.upi.edu/Direktori/FIP/JUR.../PDF/Model_Pengemban gan_Pembelajaran.pdf 
75 | MODEL INTEGRASI MATEMATIKA DENGAN NILAI ISLAM Mutijah

Suwarsono. 2015. Etnomatematika (Ethnomathematics). Handout Program S2 Pendidikan Matematika Universitas Sanata Dharma.

Tim Penyusun. 2006, Undang-undang dan Peraturan Pemerintah RI; Pendidikan, Dirjend Pendidikan Islam Departemen Agama RI.

Umbara, U. 2015. Integrasi Nilai-nilai Kearifan Lokal Budaya Masyarakat dalam Pembelajaran Matematika Realistik. Proceeding of ACER-N Meeting and Seminar Fakultas Pascasarjana Universitas Pasundan, Volume 1, Tahun 2015, ISSN 2407-8867.

Widyastini. 2004. Nilai-Nilai Islam dalam Kebudayaan Indonesia (Kajian Filsafat Nilai). Jurnal Filsafat, Jilid 37, Nomer 2, Fakultas Filsafat UGM. 